\title{
AN EDUCATIONAL OF FAMILY FRIENDLY DIGITAL MEDIA IN RPTRA RASAMALA
}

\author{
Manik Sunuantari and Sumiyati \\ Universitas Sahid, Indonesia. \\ manik_sunuantari@yahoo.com
}

\begin{abstract}
The rapid development of technology has a big impact on human life, especially in shaping the character of the young generation as the nation's successors. It takes a wise attitude in the use of appropriate technology to encourage children's creativity positively. Parents, especially mothers as the most important part of the family give a big role in the pattern of children's education. For this reason, harmonious family communication is needed in creating children's independence. To realize this, the DKI Jakarta regional government is responsible for creating a friendly social environment. One of the efforts carried out by building a Child-Friendly Integrated Public Space (RPTRA). Through the RPTRA it is expected that the community will carry out various social interactions that can encourage community socio-economic independence. The location of community service is carried out in the Rasamala RPTRA located in the Menteng Dalam village. The activity was carried out by involving the PKK of Menteng Dalam Village as a partner, as well as the manager of the RPTRA. Education about using family-friendly digital media will give parents an understanding of the right education patterns for children. This is expected to encourage children to be creative in utilizing digital media to provide added value for children. Awareness of the importance of utilizing digital media must be supported by the efforts of all parties not given entirely to children. Harmonious family communication will provide comfortable support for children in living their lives. So that child is encouraged to do positive things that support their activities. For this reason, digital media education is inevitable in shaping the nation's character.
\end{abstract}

Keywords: Digital Media Education, Family Communication, RPTRA

\section{INTRODUCTION}

The emergence of mass media in human civilization provides major changes in communication activities. Various communication activities through mass media can eliminate distance, even though space and time. Through the mass media we find out various information that occurs in any part of the world. So that formed a global community network. Network society shows that socio-cultural phenomena including social relations that occur in the digital world (Nasrullah, 2016). Digital networks are widely connected so they can connect. Every individual has the freedom to choose the media of communication and the dissemination of information. Not only choosing the media, but choosing information is also handed back to us as users. The function of mass communication according to DeVito (in Ardianto, 2017) is:

1. To persuade, in the form of changing or strengthening one's attitudes, beliefs or values; move someone; introduce existing values and systems.

2. Conference status, can increase prestige

3. Narcotization, that the information delivered makes trust and powerless

4. Creating unity, we feel to be one in the information, the feeling of the same boat

5. Privatization, tends to withdraw from the environment and live in their world

For mass media users, if they continue to consume the information presented it will have a narcotic effect. Often people immediately trust the information in the mass media without confirming the truth of the information. For that we need public awareness in the wise use of mass media. The presence of digital technology has given an inevitable explosion of information to the development of the global community.

The public experiences a flood of information, so people often experience confusion in following various news reports in the mass media. The presence of digital media is changing the process of production, distribution and consumption of the people. Information can appear anywhere and spread quickly. These conditions cause information often inaccurate because it loses with speed. One of the effects of digital technology is false information that contains lies, known as hoaxes. Millennial are very vulnerable to hoax news, because they are 
easily directed to destructive things. So that it takes critical power of the community to choose useful information that their needs.

To meet the needs of the community for space for the community to interact both within the family and social spheres, the Provincial Government of DKI Jakarta has made various efforts, one of which is building a Child Friendly Integrated Public Space (RPTRA). Provision of land for this RPTRA is a development of Green Open Space (RTH) which was built since 2015. This is done as a form of government commitment to improve the quality of life of individuals, families, groups, and society in general. With this RTRA, all community activities can be carried out, both as a center for social and economic activities. RPTRA has the following functions:

1. As a center of community activity directed at social and economic activities

2. Service facilities and integrated activities for infants and the elderly so that they can be used as a consultation center for various information for the community

3. Provision of integrated facilities for children outside of school and disabilities, namely as green land as well as public play rooms

4. Water conservation land, namely the presence of green land as ground water infiltration

5. Disaster evacuation center for the public

As a public space in the RPTRA several supporting facilities are expected to help the community in carrying out its various activities. The available facilities are: lactation room, library, PKK Mart, multipurpose room, toilet for people with disabilities, futsal field, children's playground, nutrition pool and medicinal plants. All existing facilities are directed to encourage community independence and provide adequate play space for children in densely populated areas. In general, some of the services provided by RPTRA are:

1. Services for children, consisting of:

- Youth Information and Consultation Center (PIK)

- Integrated Service Post Activities (Posyandu)

- Child friendly library

- Place of exercise

- Children's playground

- Children's creativity activities

- Children's forum activities

2. Disaster services, used as temporary shelters in the event of a disaster

3. Services to the community:

- Activity 10 Basic Programs Family Welfare Empowerment (PKK)

- PKK Mart

- Toddler and Elderly Integrated Service Post Activities (Posyandu) Services

- Place for training and community outreach activities

- Health services and Family Planning (KB)

- Complaints of violence against children and women

All activities in the scope of the RPTRA are expected to be able to synergize with community needs, so that they are encouraged to make the RPTRA the center of community activity. The availability of physical and non-physical facilities provides support in its use, especially for children. They can develop better because there is room for expression and creativity. Children will develop more directed because there are managers who work daily to accompany various activities carried out by children. The growth and development of children can be better monitored by the RPTRA.

The Rasamala RPTRA was officially opened by the Governor of DKI Jakarta Basuki Tjahaja Purnama 29 April 2016, the Rasamala RPTRA development also involved an industry, namely the Alam Sutera Company. The activity is part of the Alam Sutera corporate social responsibility (CSR) program as a form of corporate social responsibility to the community, especially gender and children. The Rasamala RPTRA is located in RW 13, Kelurahan Menteng Dalam, Tebet, and South Jakarta. It was established on an area of 1,800 square meters, so that it was expected to be an effective land for the community to carry out activities both socially and economically.

Various community activities are carried out in the RPTRA with support from the RTRA manager, including: Posyandu for Toddlers and Elders, PKK Mart, nutritional pool, medicinal plants, and providing a public library that can be utilized by residents. The manager is responsible for managing and maintaining all assets in the RPTRA environment. For the sustainability of the RPTRA, it can be done because of good cooperation between the government, the community, companies and academics. 


\section{METHODS}

The method used in community service activities in the Rasamala RPTRA consists of several stages:

Stages of the survey

Namely by surveying the Rasamala RPTRA location in Menteng Dalam, South Jakarta, to obtain various information about community needs related to community empowerment in the field of utilizing information based on digital technology. The activity began with an interview with the manager of the RPTRA and PKK management, because they were the ones who were involved in many RPTRA activities. The needs analysis is done so that the activities that will be carried out by the needs of the community.

\section{Stages of socialization}

The socialization was carried out in the form of counseling activities and training on the use of digital-based media, such as the use of mobile phones with various existing applications. The socialization was carried out at the RPTRA meeting hall, which was attended by the Lurah, RPTRA managers and academics. The activity is directed so that the participants later after the activity is finished can apply the results of the socialization in their respective families wisely.

\section{Monitoring stages}

For 3 (three) months, monitoring of the results of the socialization was carried out, namely by observing several participants in the process of children's education at home. Changes that occur in any form become the basis for future activities. So that information empowerment can be carried out on an ongoing basis as part of the process towards community independence.

\section{RESULTS AND DISCUSSION}

As one form of community empowerment that needs to be done for the people of Menteng Dalam in South Jakarta is digital media education that is environmentally friendly. Counseling activities about children's media education will provide knowledge and understanding for parents in addressing the use of various existing information media. Utilization of various mass media (newspapers, radio, television and film), online media, and social media and messenger applications must be done wisely following needs. For this reason, education is needed about the use of media so that people, especially the younger generation, are not mistaken in their use.

The Provincial Government of DKI Jakarta, as a stakeholder, is responsible for empowering the community in the use of media and information to provide added value to people's lives. Various attempts were made to provide understanding to the public to assess the appropriate media used as needed. To improve the quality of life of the people the DKI Jakarta provincial government is committed to building a friendly environment for families and children. For this reason, together with the private sector, the government is trying to make this happen by developing RPTRA. Through the RPTRA, it is hoped that Jakarta will become a livable city. This can be understood because Jakarta is one of the most densely populated areas in the world. Like Jakarta, Menteng Dalam village is one of the densely populated areas, most of its residents work as traders. The condition of houses that coincide with one another does not allow the existence of green land, all the alleys are filled with building houses.

The Rasamala RPTRA, located in the Menteng Dalam village, is open to the public every day at 05.00 a.m. to 09.00 p.m. The former school land which was used as the location of the RPTRA provided space to interact both socially and economically. Even children can also use it as a more direct playground. For housewives, they also provide opportunities for activities in various activities such as: family consultation, Posyandu, recitation, raising fish, while watching their children play at the RPTRA location. The existence of this green space allows mothers to be actively involved in building their families without having to leave their young children. 


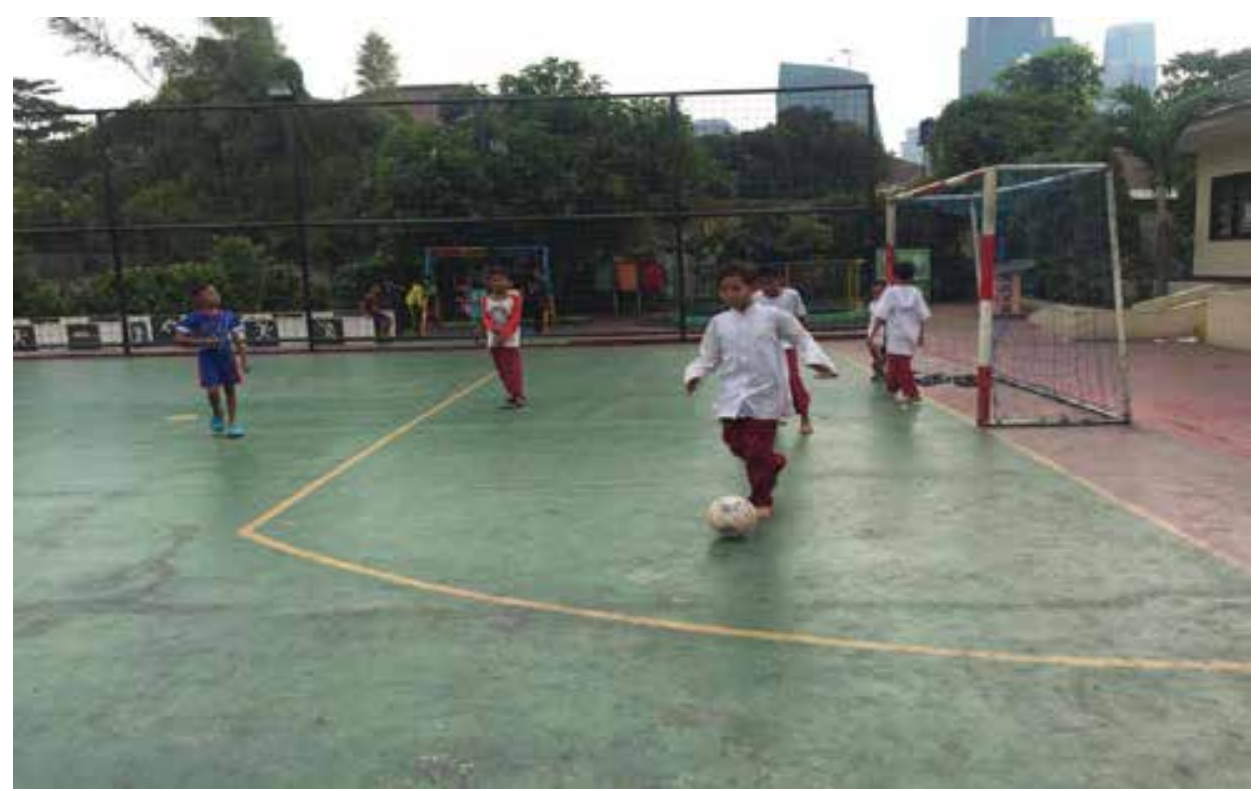

Picture 1. RPTRA Rasamala football field

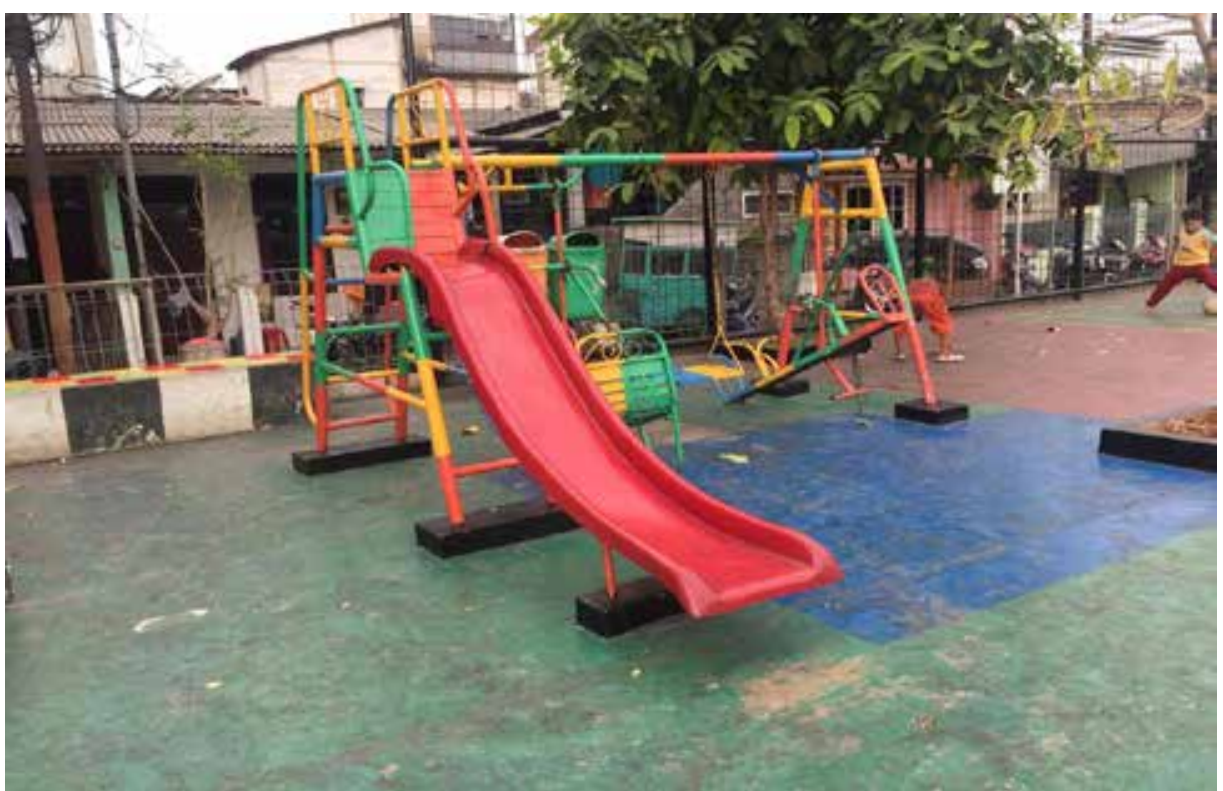

Picture 2. RPTRA Rasamala children's playground

One of the activities carried out is education about the use of internet media for families, not only parents but also children. Parents should always supervise children in the use of the media, so that children can more optimally utilize the media as friends in their activities. This means that children can utilize internet media according to their age and needs. Easy access provides opportunities for children to use media unwise. One of the current rampant news hoaxes, parents should be able to find out information that is false or not, so it is not provoked by negative things. This is where the important role of academics in providing education to parents in educating children in the use of internet media. So that parents and children are not trapped in things that tend to be destructive.

As an educational institution, universities have a responsibility to advance their environment. Through education about the use of environmentally friendly digital media, citizens will be able to evaluate the truth of information. Education must be done to form a young generation who has the character of Indonesia. Parents are expected to always assist their children in the use of various media, especially digital media. 


\section{CONCLUSION}

From the dedication activities it can be concluded that, education about the use of digital media must be often carried out by various parties. Good education will produce the next generation of a strong nation, so that it shows the true character of the nation. Public awareness in accessing, using, selecting, evaluating and evaluating information flood is urgently needed. The community must have the ability in the process of utilizing information. Parents play a role in building children's educational patterns in the use of digital media, so that environmentally friendly digital media will encourage creative and innovative children. Public awareness in accessing, using, selecting, evaluating and evaluating information flood is urgently needed. The community must have the ability in the process of utilizing information.

The process of educating digital media that is environmentally friendly, must be carried out jointly by involving various parties, namely stakeholders, in this case the Provincial Government of DKI Jakarta, which in its technical implementation is building a Child Friendly Integrated Public Space (RPTRA), one of which is the Rasamala RPTRA which is located in the Menteng Dalam village in South Jakarta. It also involves companies through CSR programs of each company, as a form of corporate responsibility for the sustainability of the community. Various forms of CSR can be developed to build a healthy environment towards community independence. Other parties involved are academics, as RPTRA partners who can provide structured education to the community as needed.

Digital media education activities are environmentally friendly for the community, especially PKK to give awareness to mothers in educating children, so that the child's growth and development always get assistance from both parents, both formal and non-formal education. With the growing awareness of the participation of parents in monitoring the use of digital media, children can choose information according to their needs. In the end they are not easily provoked by news that is of a hoax nature, because it is critical in accessing information. Besides, the public can also minimize negative content by not easily spreading fake and false news to other parties. The ability to be critical in responding to various information is continuously carried out along with technological developments. This is a shared responsibility between the government, the community, academics and business enterprises.

\section{REFERENCES}

Ardianto, E., Komala, L. dan Karlinah, S. (2017). Komunikasi Massa Suatu Pengantar, Bandung, Refika Offset

Maryani, E., Rahmawati, D., Sarjono, Sulila, K., Wulanningrum, H., Putra, HM. dan Bernadeta, Y. (2016). Saatnya Melek Media : Pengetahuan dan Rujukan Bagi Khalayak Media, Jakarta, Kementrian Komunikasi dan Informasi RI

Nasrullah. (2016). Media Sosial : Perspektif Komunikasi, Budaya, dan Sosioteknologi. Bandung, Simbiosa 